\title{
Impact of an Educational Program on Nurse's Knowledge and Practice Regarding Neonatal Jaundice
}

\author{
Afkar Ragab Mohammed, Nehad Abdel Salam Nasef, Rehab Hani EL Kazaz, \\ Walaa Abdel Khalek Elsayed Mohammed \\ Professor of Pediatric Nursing, Faculty of Nursing, Cairo University, Assistant \\ Professor of Pediatric Medicine, Faculty of Medicine, Mansoura University, Lecture \\ of Pediatric Nursing, Faculty of Nursing, Port-Said University, clinical instructor at \\ Technical Institute of Nursing.
}

\begin{abstract}
Background: Jaundice is common in the neonatal period, affecting 50.0-60.0\% of newborns. Jaundice is not a disease by itself, but rather, a sign that results from hyperbilirubinemia, the excessive accumulation of bilirubin in the blood, which has toxic effects on the body, such as kernicterus.Aim: was to determine the impact of intervention program for nurses' knowledge and practice regarding neonatal jaundice. Subject and Methods: the research design was a Quasi-experimental study. The sample consisted of 51 nurses working in NICU at Mansoura University Children Hospital. Setting: The study was conducted at Neonatal Intensive Care Unit at Mansoura University Children Hospital during the period from August, 2013 to the end of May 2014. Tools: Two tools were used for data collection, an interview questionnaire sheet to assess nurse's general characteristics and knowledge, an observational checklist to assess nurse's practiceResults: revealed that a highly statistically significant differences between pre and post educational program intervention regarding the level of knowledge and practice. Conclusion: the study concluded that the educational program is an effective method to improve nurses' knowledge and practice.Recommendations: The results of the current study recommended that, similar training programs should be implemented in similar setting.
\end{abstract}

Key Words: Educational Program, Knowledge, Neonatal Jaundice, Practice, nurses. 


\section{INTRODUCTION}

Jaundice is the most common condition that requires medical attention in newborns. The yellow coloration of the skin and sclera in newborns with jaundice is the result of accumulation of unconjugated bilirubin. In most infants, unconjugated hyperbilirubinemia reflects a normal transitional phenomenon. However, in some infants, serum bilirubin levels may raise excessively, which can be cause for concern because unconjugated bilirubin is neurotoxic and can cause death in newborns and lifelong neurologic sequelae in infants who survive kernicterus (Hansen, Itani, and Windle, 2014).

Neonates usually have high hemoglobin levels at birth, but in the early days, the red blood cells are destroyed in large volumes resulting in increased levels of bilirubin in the plasma. This is unconjugated bilirubin is fat soluble and cannot be excreted by the body. So, it travels to the liver for conjugation (Glasper, Coad, and Richardson, 2015). Unconjugated bilirubin is conjugated by the liver, making it water soluble and easily eliminated from the body through the stool (Wells, Ahmed, and Musser, 2013).

Approximately $60 \%$ of term and $80 \%$ of preterm babies develop jaundice in the first week of life, and about $10 \%$ of breastfed babies are still jaundiced at 1 month of age. According to statistics from Mansoura Children hospitals in 2012 there are 48 cases admitted to (Neonatal Intensive Care Unit) complained of jaundice. In addition to in 2013 there are 93 cases admitted to (NICU) complained of jaundice (Statistical department of $\mathrm{MCH}, 2014)$.

Jaundice is a potentially life-threatening condition that continues to affect newborns, accounting for continued hospital readmissions; health care providers worldwide recognize that severe neonatal jaundice is a "silent" cause of significant neonatal morbidity and mortality. Untreated neonatal jaundice can lead to death in the neonatal period and to kernicterus (Slusher, Zipursky, and Bhutani, 2011).

Nurses are the largest segment of the health care workforce in the world. They are involved in virtually all levels of health care and are often the central points of contact for the clinical care of people. So, the preparation received by nurses at various levels of training and career affects their roles in prevention and care. To provide effective care, nurses need to be equipped with appropriate knowledge and skills. The published data have recommended that, the trainings should focus on personal experiences and group support (Mockiene et al., 2011).

\section{Significance of the study:}

Click et al (2013) emphasized that, the nurses play an integral role in the implementation of universal screening for elevated bilirubin levels in the newborn. Excessive rise in serum bilirubin levels can cause neonatal death and lifelong neurologic sequelae (kernicterus), including cerebral palsy and hearing loss. So, infants who develop jaundice need close monitoring and severe neonatal jaundice requires immediate medical attention. Hence, some knowledge about the risks, 
complications, early detection of neonatal jaundice and its management by nurses is important. Therefore, this study was designed to conduct an educational program regarding neonatal jaundice to assess its effect on nurses' knowledge and practices.

\section{AIM OF THE STUDY:}

The aim of this study is to evaluate the effect of an educational program on nurses' knowledge and practice regarding neonatal jaundice.

\section{Research Hypothesis:}

The educational program will improve nurses' knowledge and practice regarding neonatal jaundice.

\section{SUBJECTS AND METHODS:}

Research Design: A quasi-experimental design was used in this study.

Setting: this study conducted at Neonatal Intensive Care Unit, which affiliated to Mansoura University Children Hospital.

Sample: A convenience sample of 51 nurses was recruited in this study .

\section{Tools of Data Collection:}

Three tools were used to collect the necessary data for the study as follows:

\section{Tool (1): Pre-designing Questionnaire Sheet:}

It was developed by the researcher after reviewing the related literature to collect personal data, characteristics of newborn, and nurses' knowledge regarding neonatal jaundice (it consists of 67 open ended questions. The total score was estimated by summing scores of each item and divided it on the number of questions, whereas (2) scores were given to completely correct answer, (1) for incompletely correct answers, while (0) incorrect answer. The level of knowledge was categorized into three levels; good $(75.0 \leq 100.0 \%)$, average $(60.0 \leq 75.0 \%)$, and the poor level $(<60.0 \%)$.

\section{Tool (2): An Observational Checklist:}

It was adapted from Boden and Greenberg (2012) to assess the actual nursing care provided by nurses for neonates with hyper-bilirubinemia as regards phototherapy, exchange transfusion, breast feeding, bottle feeding and gavage feeding, hygienic care (sponge care, eye care and mouth care) and monitor bilirubin level regularity. Each nurse was observed and evaluated using the observation checklists, which were filled in by the researcher. The nurse's practice was scored as; (1) for done, and (0) for not done. The total scores of nurse's practice were (200) marks of (100) items for all the nursing procedures, whereas good level $(75 \leq 100 \%)$, the average level $(60 \leq 75 \%)$, and the poor level $(<60.0 \%)$.

\section{Proposed Educational Program:}

It was constructed by the researcher. It consists of two parts; the first part concerns with knowledge about neonatal jaundice as definition, incidence, pathophysiology, risk factors, classification and clinical pictures of neonatal jaundice, causes, diagnosis, complications, and finally the management of neonatal jaundice. While, the second 
part deals with the practice such as; nursing care of infants under phototherapy (before, during and after the procedure), feeding (breast feeding, bottle feeding and gavage feeding), hygienic care (sponge care, eye care and mouth care), and bilirubin level monitoring.

Operational Design: The operational design includes preparatory phase, and content validity and reliability.

\section{Preparatory Phase:}

It was included revision of related literature, and theoretical knowledge of various aspects of the study using books, articles, internet periodicals and magazines to develop the tools for data collection.

\section{Content Validity:}

The tool was tested for content validity by seven expert nurse educators in the field of pediatric nursing from the Faculty of Nursing, Port-Said University. Necessary modifications were done according to the experts' recommendations.

\section{Pilot study:}

A pilot study was conducted on $10.0 \%$ of the total sample to test the feasibility of the study and applicability of the tool and to find out the possible obstacles and problems that might face the researcher and interfere with data collection and to detect any problems peculiar to the statements as sequence of questions and clarity. It also helped to estimate the time needed for data collection. After conducting the pilot study, it was found that the sentences of the tools were clear and relevant, but few modifications were done according to the pilot study results. The nurses included in the pilot study were excluded from the main study sample. Cronbach alpha coefficient was used to assess the internal consistency of the tool and its values were (0.83).

\section{Field work:}

The study proceeded as follows:

-Written approvals were obtained from the hospital directors as well as nursing directors after explaining the aim of study in order to obtain their permission and cooperation.

- The current study was carried out over a period of 10 months from the beginning of August, 2013 to the end of May, 2014.

- Before distributing the questionnaire, the purpose of the study was explained to each nurse, and then the questionnaire sheet (tool 1) was distributed to all nurses and filled in with the presence of the researcher to ensure that questions were answered by the nurse on her own, and that all questions were completed; it lasts about 30-45 minutes.

- The researcher observed the performance of each nurse while providing actual care for neonates by indirect observation guided by observational checklist (tool 2 ). The time consumed for assessing phototherapy procedure took 20-30 minutes and approximately 5-10 minutes for each other procedure. 
- Nurses were divided into small groups (5-10 nurses). The educational program was given in three sessions (around 30-40 minutes for each). Various teaching methods were used in the form of lectures, group discussion, demonstration and re-demonstration. Various teaching media were used such as power point, videos and hand out.

- Reassessment of nurses knowledge and practice after immediately after applying the program.

\section{Ethical Consideration:}

The purpose of the study was explained to each nurse and a written consent was obtained from each of those who agreed to participate. They were assured about confidentiality and privacy and that this information will be used only for research purposes only. Each participant was informed about her right to withdraw from the study at any time without giving any reason.

\section{Statistical Analysis of Data:}

Data was analyzed using SPSS (Statistical Package for Social Sciences) version 15. Qualitative data were presented as number and percent. Comparison between groups was done by Chi-Square test. Quantitative data were presented as mean $\pm \mathrm{SD}$. P < 0.05 was considered to be statistically significant.

\section{RESULTS:}

The main findings of the present study were:

Table (1): shows that, the mean age of nurses under the study is $(29.57 \pm 6.21)$ years. Regarding to nurses' qualification, the majority of nurses $(82.4 \%)$ has higher education (Bachelor degree). It reveals that, $62.7 \%$ of the studied nurses has 1-5 years of experience in NICUs, with mean of (7.36 \pm 6.22$)$ years. More than two thirds of the nurses $(72.5 \%)$ hasn't attended previous training courses regarding neonatal care.

Table (2): illustrates that, about two thirds of the studied neonates $(64.7 \%)$ were males. As regards to gestational age, more than half $(58.8 \%)$ of them were less than 37 weeks. It was observed that, the mean age per days was $(11.41 \pm 11.98)$. The same table reveals that, the majority of neonates $(84.3 \%)$ were delivered by CS, and their mean birth weight was $(2228.04 \pm 675.88)$ grams.

Table (3): shows that, there was a statistically significant difference between before and after total scores regarding nurses' knowledge whereas $(\mathrm{p}<0.05)$.

Table (4): reveals that, there was a statistically significant difference between before and after total scores regarding nurses' knowledge whereas $(p<0.05)$. 
Table (1): Frequency distribution of the studied nurses according to their personal and professional characteristics $(\mathrm{N}=51)$

\begin{tabular}{|c|c|c|c|}
\hline \multicolumn{2}{|c|}{ Personal and professional characteristics } & \multirow{2}{*}{\begin{tabular}{|l|} 
No \\
27 \\
\end{tabular}} & \multirow{2}{*}{\begin{tabular}{|l|}
$\%$ \\
52.9
\end{tabular}} \\
\hline Age in years & $20>25$ & & \\
\hline & $25>35$ & 17 & 33.3 \\
\hline & $>35$ & 7 & 13.7 \\
\hline Mean \pm SD & \multicolumn{3}{|l|}{$29.57 \pm 6.21$} \\
\hline \multirow[t]{3}{*}{ Educational level } & $\begin{array}{l}\text { Secondary school nursing } \\
\text { diploma }\end{array}$ & 5 & 9.8 \\
\hline & $\begin{array}{l}\text { Technical institute of } \\
\text { nursing }\end{array}$ & 4 & 7.8 \\
\hline & $\begin{array}{l}\text { Bachelor degree in } \\
\text { nursing }\end{array}$ & 42 & 82.4 \\
\hline \multirow[t]{4}{*}{ Years of experience in NICU } & $1>5$ & 32 & 62.7 \\
\hline & $5>10$ & 14 & 27.5 \\
\hline & $>10$ & 5 & 9.8 \\
\hline & Mean \pm SD & \pm 6 & \\
\hline \multirow[t]{2}{*}{ Training programs } & Yes & 14 & 27.5 \\
\hline & No & 37 & 72.5 \\
\hline \multirow[t]{2}{*}{ No. of training programs $(n=14)$} & One course & 12 & 85.7 \\
\hline & More than one course & 2 & 14.3 \\
\hline
\end{tabular}


Table (2): Frequency distribution of the studied neonates according to their general characteristics $(\mathrm{N}=51)$

\begin{tabular}{|l|l|l|}
\hline Neonates' Characteristics & No & \% \\
\hline $\begin{array}{l}\text { Age (day) } \\
\text { Minimum } \\
\text { Maximum }\end{array}$ & \multicolumn{2}{|l|}{} \\
& \multicolumn{2}{|l|}{} \\
\hline Mean \pm SD & 45 \\
\hline Gender & \multicolumn{2}{|l|}{$11.41 \pm 11.98$} \\
\hline Male & \multicolumn{2}{|l|}{} \\
\hline Female & 33 & 64.7 \\
\hline Gestational age (Weeks) & 18 & 35.3 \\
\hline$>37$ w & & \\
\hline $37>42$ w & 30 & 58.8 \\
\hline$<42$ w & 17 & 33.3 \\
\hline Mode of delivery & 4 & 7.8 \\
\hline \multicolumn{1}{|l|}{ Normal vaginal delivery (NVD) } & \multicolumn{2}{|l}{} \\
\hline \multicolumn{1}{|l|}{ Cesarean section (CS) } & 8 & 15.7 \\
\hline Birth weight (Grams) & 43 & 84.3 \\
\hline & \multicolumn{2}{|l}{} \\
\hline Minimum & 965 & \\
\hline Maximum & 3200 \\
\hline Mean \pm SD & $2228.04 \pm 675.88$ \\
\hline
\end{tabular}

Table (3): Total scores of the studied nurses according to their level of knowledge regarding neonatal jaundice $(\mathrm{N}=51)$

\begin{tabular}{|c|c|c|c|c|}
\hline Total Score & Category & No & $\%$ & Significance \\
\hline \multirow[t]{3}{*}{ Pre-program } & Good & 12 & 23.5 & \multirow{6}{*}{$<0.05^{*}$} \\
\hline & Average & 25 & 49.0 & \\
\hline & Poor & 14 & 27.5 & \\
\hline \multirow[t]{3}{*}{ Post-program } & Good & 45 & 88.2 & \\
\hline & Average & 5 & 9.8 & \\
\hline & Poor & 1 & 2.0 & \\
\hline
\end{tabular}


Table (4): Total scores of the studied nurses according to their level of practice regarding neonatal jaundice $(\mathrm{N}=51)$

\begin{tabular}{|l|l|l|l|l|}
\hline Total Score & Category & No & $\%$ & \multirow{2}{*}{ Significance } \\
\hline Pre-program & Good & 1 & 2.0 & \\
\cline { 2 - 4 } & Average & 9 & 17.6 & \multirow{2}{*}{$<0.05^{*}$} \\
\cline { 2 - 4 } & Poor & 41 & 80.4 & \\
\hline Post-program & Good & 49 & 96.1 & \\
\cline { 2 - 4 } & Average & 2 & 3.9 & \\
\cline { 2 - 4 } & Poor & 0 & 0.0 & \\
& & & & \\
& & & & \\
\end{tabular}

\section{DISCUSSION:}

The aim of the present study was to evaluate the effect of an educational program on nurses' knowledge and practice regarding neonatal jaundice. This aim was highly significantly achieved through the present study findings and the hypothesis was accepted. According to the results yielded by the present study, the educational program had a positive effect on nurses' knowledge and practice with a statistically significant difference $(\mathrm{p}<0.05)$.

Regarding nurses' knowledge, the findings of the current study revealed that, the highest percentage of the studied nurses had a good level of knowledge after the intervention program. This result indicates the effectiveness of the program on nurses' knowledge and practice regarding neonatal jaundice. So, health care professionals should always be encouraged to update their knowledge and maintain clinical competence.

The findings of the current study were gone on the same line with Jeffery and Kocova (2004) who stated that, the implementation of effective training programs for health care providers in hospital settings, followed by improvement in Essential Newborn Care (ENC).With respect, the finding was in disagreement with Mohammed, Soliman, and Morsy (2009) who revealed that, the nurses' factors related to in service training had no effect on both nurses' knowledge and performance.

As results yielded by the present study, the majority of nurses had a poor level regarding practice; it may be due to lack of nurses' awareness about the care of neonates with hyper-bilirubinemia, lack of continuous training, supervision and guidance, and inadequate knowledge. The actual nurses' practice regarding neonatal jaundice was improved after the educational program. This result was supported by 
Mohammed (2010). Moreover, Stokowski (2011) recommended that, proper nursing care enhanced the effectiveness of phototherapy and minimizes complications through maximizing skin exposure, providing eye protection and eye care, careful attention to thermoregulation, maintaining adequate hydration, promoting elimination, and supporting parent-infant interaction.

In addition, Shrestha (2013) concluded that, the overall assessment of knowledge and practice of nursing personnel regarding phototherapy showed that, nurses had a high level of knowledge and they had also applied good practice during the care of the baby with phototherapy after program implementation.

The results in the current study were congruent with Fahad et al (2013) who studied nurses knowledge versus their performance regarding the care of neonates undergoing phototherapy, and they founded that, appropriate nursing care also minimized the potential side effects and complications, and enhanced the effectiveness of phototherapy, moreover performance done by the neonatal nurse was influenced mainly by their wide base of knowledge.

The findings of the current study were incongruent to Ahmed, Shoulah, AlSharkawy, and Mahmoud (2009) who concluded that, $63.3 \%$ of nurses were incompetent about feeding through gravity. While, Kuo, Chen, Lin, Lee, and Hsu (2009) indicated that, newborn-care education programs achieved successful promotion in newborn care and provided health professionals with evidence-based intervention. In addition, El-Sayed, Sabry, Sharkawy, El-Sayed, and Ali (2013) concluded that, all the nursing activities presented in the initial standard as basic nursing responsibilities were enhanced after implementing the educational program.

The present study results showed improvement in nurses' knowledge and practice level so that, the current study recommended continuous educational programs. These results were supported by the National Association of Neonatal Nurses (2010) recommendations; nurses should achieve higher levels of education and training to respond to the increasing demands and complexity of neonatal health care, educational programs for nurses seeking advanced practice degrees should provide a seamless transition into these higher degree programs.

In the same field Rubens and Victora (2010) concluded that, the shortages of qualified health workers and inadequate training and skills for the care of premature babies were a major reason for poor progress in reducing neonatal deaths. Nurses or midwives with skills in critical areas such as resuscitation, safe oxygen management, and breastfeeding support were the frontline worker for premature babies.

\section{CONCLUSION:}

In the light of the findings of the current study, it can be concluded that, the level of nurses' knowledge and practice regarding neonatal jaundice were poor and were improved after the educational program. So, the educational programs are an effective 
way to improve nurses' level regarding knowledge and practice, which has a positive effect on newborn health status.

\section{RECOMMENDATION:}

Based on the findings of the present study, the following is recommended:

Similar training programs should be implemented in similar setting.

\section{REFERENCES:}

Ahmed, F., Shoulah, A., Al-Sharkawy, S., \& Mahmoud, F. (2009): Quality of nursing care for high risk neonate receiving nasogastric tube feeding. Un published Master Thesis, Faculty of Nursing, Benha University.

Click, R., Smith, J., Fowler, L., DuBose, J., Saxton, M., \& Herbert, J. (2013): An osteopathic approach to reduction of readmissions for neonatal jaundice; 5(1): 17-23.

El-Sayed, M., Sabry, Y., Sharkawy, M., El-Sayed, M., \& Ali, T. (2013): Establishing basic standards of nursing care protocol at Neonatal Intensive Care Unit. Nature and Science; 11(4): 86-92.

Fahad, H. (2013): Nurses knowledge versus their performance regarding the care of neonates undergoing phototherapy. Unpublished master Thesis in pediatric department, Faculty of nursing, Alexandria University.

Glasper, A., Coad, J., \& Richardson, J. (2015): Children and young people's nursing at a glance, Jaundice and hyperbilirubinemia, Illustrated Textbook of Pediatrics, 1st ed; John Wiley \& Sons, Ltd., pp98.

Hansen, T., Itani, O., \& Windle, M. (2014): Neonatal jaundice. Retrieved from: http://emedicine.medscape.com/article/ 974786-overview\#a0199.

Jeffery, H., \& Kocova, M. (2004): The impact of evidence based education on perinatal capacity- building initiative in Macedonia, Medical Education; 38, 435-447.

Kuo, S.C., Chen, Y.S., Lin, K.C., Lee, T.Y., \& Hsu, C.H. (2009): Evaluating the effects of an Internet education programme on newborn care in Taiwan. J Clin Nurs; 18(11): 1592-601. doi: 10.1111/j.1365-2702.2008.02732.x.

Mockiene, V., Suominen, T., Valimaki, M., Razbadauskas, A., Martinkenas, A., \& Caplinskas, S. (2011): The impact of an education intervention to change nurses' HIV-related knowledge and attitudes in Lithuania: a randomized controlled trial. Journal of Association of Nurses in AIDS Care; 22(2): 141.

Mohammed, H. (2010): Nurses' knowledge and practice regarding care given for neonates with hyperbilirubinemia. Unpublished Master thesis Degree in pediatric Department, Faculty of Nursing. Cairo University. 
Mohamed, H., Soliman, N., \& Morsy, M. (2009): Assessment of nursing care given for high risk neonates. Unpublished Master thesis Degree in pediatric Department, Faculty of Nursing.

National Association of Neonatal Nurses. (2010): Prevention of acute bilirubin encephalopathy and kernicterus in newborns.

Rubens, E., \& Victora, G. (2010): Global report on preterm birth and stillbirth (4 of 7): delivery of interventions. BMC Pregnancy Childbirth; 10(1): S4.

Shrestha, S. (2013): Knowledge and practice of nursing personnnel regarding the care of neonates under phototherapy at Paropakar Shree Panch Indra Rajyalaxmi Devi Prasuti Griha, Thapathali, Kathmandu. Journal of Kathmandu Medical College; 2(2).

Slusher, T., Zipursky, A., \& Bhutani, V. (2011): A global need for affordable neonatal jaundice technologies; seminars in perinatology. Newborn Jaundice Technologies; 35(3): 185-191.

Stokowski, L. (2011): Reviewing the needs of jaundice management. Advances in Neonatal Care; 11(5S): S1-S2.

Wells, C., Ahmed, A., \& Musser, A. (2013): Strategies for neonatal hyperbilirubinemia: a literature review. Lippincott Williams \& Wilkins; 38(6). 


\section{تأثير برنامج تدريبى عن مرض الصفراء فى حديثى الولادة على معلومات وممارسات الممرضات بمستشفى الأطفال الجامعى بالمنصورة}

$$
\text { أ.د/ أفكار رجب محمد، أ.م .د / نهاد عبد السلام ناصف، د/ رحاب هانى القزاز }
$$

أستاذ تمريض الأطفال كلبة التمريض - جامعة القاهرة ، أستاذ مساعد بقسم الأطفال وحديثى الو لادة كلية

الطب - جامعة المنصورة ، مدرس تمريض الأطفال كلية التمريض - جامعة بورسعيد

\section{الخلاصة}

اليرقان الوليدي هو تلون أصفر في الجلد و بياض العين.و سبب هذا التلون زيادة مادة صفراء تسمى البيليروبين.كما ان الاطفال الذين يعانون من مستويات عالية من البيليروبين في الدم تسمى فرط بيليروبين الدم.اذ تهدف هذه الدراسه الى اعداد وتنفيذ برنامج تعليمى لمعلومات و أداء الممرضات أثناء تقديم الرعاية للأطفال حديثى الولادة المصابين بمرض الصفراء بمستشفى الأطفال الجامعى وتقييم مدى تأثيره ، وقد اجريت هذه

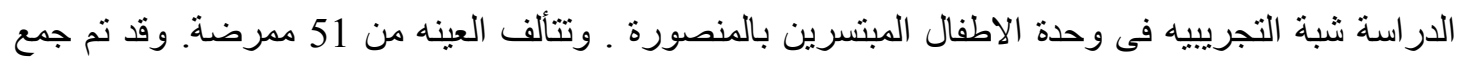
البيانات باستخدام ورقة استبيان مقابله لتقييم معلومات الممرضات و استمارة ملاحظة أدائهن قبل وبعد البرنامج . وقد أثنارت نتائج هذه الدراسة الى أن منوسط أعمار الممرضات كان 29.57 عام،وكان مستوى أقل من نصف الممرضات "متوسطأ" نسبة الى معلوماتهن وذلك قبل تطبيق البرنامج ولكن بعد نطبيق البرنامج كانت الغالبية

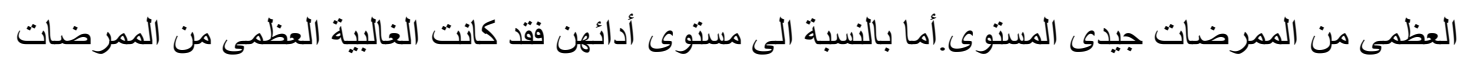
ضعيفى المستوى وذللك قبل تطبيق البرنامج ولكن بعد تطبيق البرنامج كانت الغالبية العظمى منهن جيدى

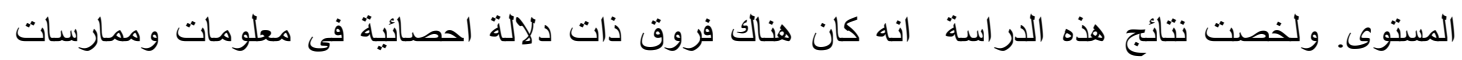

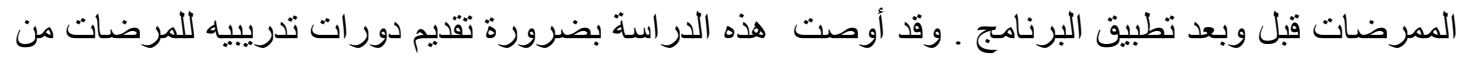
اجل الارتقاء بمعلوماتهن وممارساتهن مما سينعكس بصورة ايجابية على الر عاية التمريضية وبالتالى على صحة 